Edutech, Tahun 14, Vol.1, No.3, Oktober 2015

\title{
CHARACTER EDUCATION MODEL BASED ON EDUCATION IN ISLAMIC BOARDING SCHOOL
}

\section{MODEL PENDIDIKAN KARAKTER BERBASIS PENDIDIKAN DI PESANTREN}

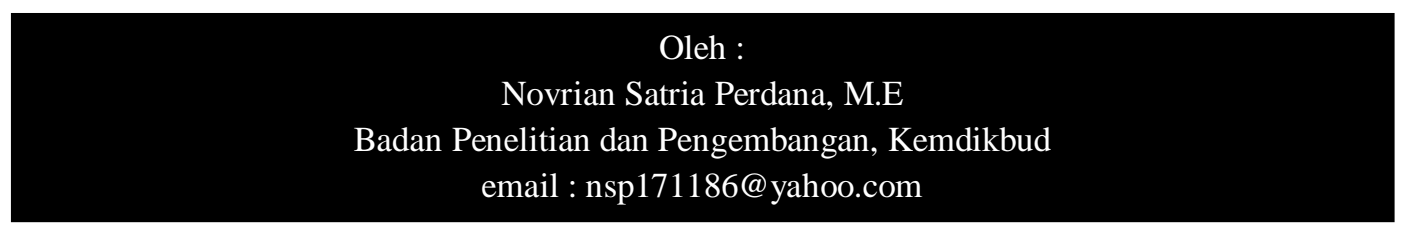

Abstract, Various efforts to make education more meaningful for individuals concerning affective domain has been conducted through several subjects, including Religion Education, Civics Education, Social Sciences Education, Indonesian Language Education, and Physical Education. However, those efforts could not effectively hold character building which is dynamic and adaptive to fast changing era. The failure of character building at formal school must be anticipated, so it is necessary to develop relevant teaching model and education system. The problem of character education in school which is not yet able to build students' character is affected by several factors: school management, teacher, and learning model. Some researches on best practices of character educationhave been conducted in order to obtain relevant teaching model at several Islamic boarding schools in North Sumatera Province, Nangroe Aceh Darussalam Province, West Sumatera Province, Riau Province, Jambin Province and South Sumatera Province. The data was collected using indepth-interview and observation. It was found that salafiyah Islamic boarding school put more priority on teacher (ustadz) role model, while modern Islamic boarding school applied tight rules to develop students' discipline, and responsibility. Islamic boarding schools build the characters of caring for other people, sincerity of devotion, modesty, and independence. The policy that could be suggested based on this research is that of the application of character education must be holistically embedded in school program and must be comprehended and obeyed by school's educators and students alikeBetter implementation could be achieved if the character education is explicitly formulated in the mission statement of the school.

Keywords: character education, learning model, Islamic boarding school

Abstrak, Berbagai upaya untuk menjadikan pendidikan lebih mempunyai makna bagi individu yang menyentuh tataran afektif telah dilakukan melalui mata pelajaran Pendidikan Agama, Pendidikan Kewarganegaraan, Pendidikan IPS, Pendidikan Bahasa Indonesia, dan Pendidikan Jasmani. Namun demikian upaya-upaya tersebut ternyata belum mampu mewadahi pengembangan karakter secara dinamis dan adaptif terhadap perubahan jaman yang sangat cepat. Permasalahan gagalnya pendidikan formal di sekolah dalam membentuk karakter siswa sangat perlu diantisipasi, sehingga perlu dikembangkan suatu model pembelajaran dan system pendidikan yang dapat digunakan untuk membentuk karakter siswa. Permasalahan pendidikan di sekolah yang belum dapat membentuk karakter siswa dipengaruhi oleh beberapa factor, diantaranya factor manajemen sekolah, guru, dan model pembelajaran. Untuk memperoleh model pembelajaran yang cocok, telah dilakukan penelitian tentang best practices pendidikan karakter di beberapa pesantren yang berada di propinsi Sumatera Utara, propinsi Nangroe Aceh Darussalam, propinsi Sumatera Barat, propinsi Riau, propinsi Jambi, dan propinsi Sumatera Selatan. Pengumpulan data dalam penelitian ini dilakukan dengan dua tehnik yang lazim digunakan dalam penelitian dalam penelitian kualitatif, yaitu; observasi dan wawancara mendalam. Ditemukan bahwa pesantren salafiyah lebih mengutamakan keteladanan ustadz, sedangkan pesantren modern menerapkan aturan yang ketat untuk menumbuhkan sikap disiplin dan tanggungjawab. Pesantren 
menumbuhkan atribut karakter saling tolong menolong, ihklas mengabdi, kesederhanaan, dan kemandirian. Kebijakan yang dapat diambil berdasarkan hasil penelitian ini adalah menerapkan pendidikan karakter secara holistic melalui program sekolah yang harus dipahami dan dipatuhi oleh semua unsur pendidik dan peserta didik. Untuk itu, lembaga pendidikan seharusnya menetapkan misi yang eksplisit terkait pengembangan karakter siswa.

Kata Kunci: pendidikan karakter, model pembelajaran, pondok pesantren

\section{A. PENDAHULUAN}

Komitmen nasional tentang perlunya pendidikan karakter secara imperatif tertuang dalam Undangundang Nomor 20 Tahun 2003 tentang Sistem Pendidikan Nasional. Dalam Pasal 3 dinyatakan bahwa "Pendidikan nasional berfungsi mengembangkan kemampuan dan membentuk watak serta peradaban bangsa yang bermartabat dalam rangka mencerdaskan kehidupan bangsa, bertujuan untuk berkembangnya potensi peserta didik agar menjadi manusia yang beriman dan bertakwa kepada Tuhan Yang Maha Esa, berakhlak mulia, sehat, berilmu, cakap, kreatif, mandiri, dan menjadi warga negara yang demokratis serta bertanggung jawab". Secara akademik, pendidikan karakter dimaknai sebagai pendidikan nilai, pendidikan budi pekerti, pendidikan moral, pendidikan watak, yang tujuannya mengembangkan kemampuan peserta didik untuk memberikan keputusan baik-buruk, memelihara apa yang baik itu, dan mewujudkan kebaikan itu dalam kehidupan sehari-hari dengan sepenuh hati. Karena itu muatan pendidikan karakter secara psikologis mencakup dimensi moral reasoning, moral feeling, dan moral behavior (Lickona, 1991).

Beranjak dari situasi tersebut di atas, terlihat bahwa pendidikan nilai/moral memang sangat diperlukan atas dasar argument : 1) adanya kebutuhan nyata dan mendesak; 2) proses tranmisi nilai sebagai proses peradaban; 3) peranan sekolah sebagai pendidik moral yang vital pada saat melemahnya pendidikan nilai dalam masyarakat; 4) tetap adanya kode etik dalam masyarakat yang sarat konflik nilai; 5) kebutuhan demokrasi akan pendidikan moral; 6) kenyataan yang sesungguhnya bahwa tidak ada pendidikan yang bebas nilai; 7) persoalan moral sebagai salah satu persoalan dalam kehidupan, dan 8) adanya landasan yang kuat dan dukungan luas terhadap pendidikan moral di sekolah. Keseluruhan argumen tersebut tampaknya masih relevan untuk 
menjadi cerminan kebutuhan akan pendidikan nasional. Sampai saat ini, pendidikan nilai/moral di Indonesia secara kurikuler telah dilakukan pada saat ini. Proses demokasi yang berbagai upaya untuk menjadikan semakin meluas dan tantangan pendidikan lebih mempunyai makna globalisasi yang semakin kuat dan bagi individu yang tidak sekadar beragam di satu pihak dan dunia memberi pengetahuan pada tataran pendidikan di berbagai jalur, jenjang, koginitif, tetapi juga menyentuh tataran dan jenis yang lebih mementingkan afektif dan konatif melalui mata penguasaan dimensi pengetahuan pelajaran Pendidikan Agama, (knowledge) dan hampir mengabaikan Pendidikan Kewarganegaraan, pendidikan nilai/moral saat ini, Pendidikan IPS, Pendidikan Bahasa merupakan alasan yang kuat bagi Indonesia, dan Pendidikan Jasmani. Indonesia untuk membangkitkan Namun demikian harus diakui karena komitmen dan melakukan gerakan kondisi jaman yang berubah dengan nasional pendidikan karakter.

Dalam konteks kehidupan cepat, maka upaya-upaya tersebut bermasyarakat, berbangsa, dan pengembangan karakter secara dinamis bernegara Indonesia, diyakini bahwa dan adaptif terhadap perubahan nilai dan karakter yang secara legal- tersebut.

formal dirumuskan sebagai fungsi dan

Oleh karena itu pendidikan karakter tujuan pendidikan nasional, harus perlu dirancang-ulang dan dikemas dimiliki peserta didik agar mampu kembali dalam wadah yang lebih menghadapi tantangan hidup pada saat komprehensif dan lebih bermakna. ini dan di masa mendatang. Karena itu, Pendidikan karakter perlu pengembangan nilai yang bermuara direformulasikan dan pada pembentukan karakter bangsa direoperasionalkan melalui yang diperoleh melalui berbagai jalur, transformasi budaya dan dimensi jenjang, dan jenis pendidikan, akan kehidupan. Kebutuhan tersebut bukan mendorong mereka menjadi anggota hanya dianggap penting tetapi sangat masyarakat, anak bangsa, dan warga mendesak mengingat berkembangnya negara yang memiliki kepribadian godaan-godaan (temptations) dewasa unggul seperti diharapkan dalam tujuan ini marak dengan tayangan dalam media 
cetak maupun non-cetak (televisi, jaringan maya, dan lain-lain) yang memuat fenomena dan kasus perseteruan dalam berbagai kalangan yang memberi kesan seakan-akan bangsa kita sedang mengalami krisis etika dan krisis kepercayaan diri yang berkepanjangan. Pendidikan karakter bangsa diharapkan mampu menjadi alternatif solusi berbagai persoalan tersebut. Kondisi dan situasi saat ini tampaknya menuntut pendidikan karakter yang perlu ditransformasikan sejak dini, yakni sejak pendidikan anak usia dini dan pada tahap pendidikan dasar secara holistik dan berkesinambungan. Permasalahan yang dihadapi adalah gagalnya pendidikan formal di sekolah dalam membentuk karakter siswa, sehingga perlu dikembangkan suatu model pembelajaran dan system pendidikan yang dapat digunakan untuk membentuk karakter siswa. Penelitian ini menelaah best practices yang diterapkan di pondok pesantren sebagai dasar pengembangan model dan system pendidikan karakter bagi sekolah formal.Karakter adalah nilai-nilai yang melandasi perilaku manusia berdasarkan norma agama, kebudayaan, hukum/konstitusi, adat istiadat, dan estetika. Pendidikan karakter adalah upaya yang terencana untuk menjadikan peserta didik mengenal, peduli dan menginternalisasi nilai-nilai sehingga peserta didik berperilaku sebagai insan kamil. Pendidikan karakter adalah suatu sistem penanaman nilai-nilai perilaku (karakter) kepada warga sekolah yang meliputi pengetahuan, kesadaran atau kemauan, dan tindakan untuk melaksanakan nilai-nilai, baik terhadap Tuhan Yang Maha Esa (YME), diri sendiri, sesama, lingkungan, maupun kebangsaan sehingga menjadi manusia insan kamil. Undang-undang Sistem Pendidikan Nasional Pasal 3 menyebutkan Pendidikan nasional berfungsi: Mengembangkan kemampuan dan membentuk karakter serta peradaban bangsa yang bermartabat dalam rangka mencerdaskan kehidupan bangsa. Pendidikan nasional bertujuan untuk berkembangnya potensi peserta didik agar menjadi manusia yang beriman dan bertakwa kepada Tuhan Yang Maha Esa, berakhlak mulia, sehat, berilmu, cakap, kreatif, mandiri, dan menjadi warga negara yang demokratis serta bertanggung jawab. Ternyata pembelajaran di sekolah yang kurang tepat merupakan salah satu factor 
kegagalan pendidikan karakter, seperti yang dikemukakan oleh Kessler (2000),"Many classroom are sprititually empty not by accident, but by design".. Namun, pendidikan karakter bukanlah semata-mata tanggung jawab pemerintah, melainkan juga orangtua, institusi pendidikan, organisasi agama, dan masyarakat.

Rich (2008) mengemukakan pentingnya beberapa keterampilan yang terkait atribut karakter, yakni: Confidence, Motivation, Effort, Responsibility, Initiative, Perseverance, Caring, Teamwork, Common Sense, Problem Solving, Focus, Respect.Athur (2003) menyatakan: "Character can be said to be the sum total of a person's characteristics, affective, cognitive and physical". Secara psikologis dan sosial kultural pembentukan karakter dalam diri individu merupakan fungsi dari seluruh potensi individu manusia (kognitif, afektif, konatif, dan psikomotorik) dalam konteks interaksi sosial kultural (dalam keluarga, sekolah, dan masyarakat) dan berlangsung sepanjang hayat. Atribut karakter dalam konteks totalitas proses psikologis dan sosial-kultural tersebut dapat dikelompokan dalam: Olah Hati (Spiritual and emotional development),
Olah Pikir (intellectual development), Olah Raga dan Kinestetik (Physical and kinestetic development), dan Olah Rasa dan Karsa (Affective and Creativity development).

Pada tahap mikro, pendidikan karakter ditata sebagai berikut :

1. Secara mikro, pengembangan nilai/karakter dapat dibagi dalam empat pilar yakni: kegiatan belajar mengajar di kelas, kegiatan keseharian dalam bentuk budaya satuan pendidikan (school culture), kegiatan ko-kurikuler dan/atau ekstra kurikuler, serta pada keseharian di rumah dan dalam masyarakat,

2. Dalam kegiatan belajar mengajar di kelas, pengembangan nilai/karakter dilaksanakan dengan menggunakan pendekatan integrasi dalam semua mata pelajaran (embedded approach). Khusus, untuk mata pelajaran Pendidikan Agama dan Pendidikan Kewarganegaraan, karena memang misinya adalah mengembangkan nilai dan 
sikap, maka pengembangan nilai/karakter harus menjadi fokus utama yang dapat menggunakan berbagai strategi/metode pendidikan nilai (value/character education). Untuk kedua mata pelajaran tersebut, nilai/karakter dikembangkan sebagai dampak pembelajaran (instructional effects) dan juga dampak pengiring (nurturant effects). Sementara itu, untuk mata pelajaran lainnya, yang secara formal memiliki misi utama selain pengembangan nilai/karakter, wajib dikembangkan kegiatan yang memiliki dampak pengiring (nurturant effects) berkembangnya nilai/karakter dalam diri peserta didik.

3. Dalam lingkungan satuan pendidikan dikondisikan agar lingkungan fisik dan sosiokultural satuan pendidikan memungkinkan para peserta didik bersama dengan warga satuan pendidikan lainnya terbiasa membangun kegiatan keseharian di satuan pendidikan mencerminkan perwujudan nilai/karakter.

4. Dalam kegiatan ko-kurikuler, yakni kegiatan belajar di luar kelas yang terkait langsung pada suatu materi dari suatu mata pelajaran, atau kegiatan ekstra kurikuler, yakni kegiatan satuan pendidikan yang bersifat umum dan tidak terkait langsung pada suatu mata pelajaran, seperti kegiatan Dokter Kecil, Palang Merah Remaja, Pecinta Alam, dan lain-lain, perlu dikembangkan proses pembiasaan dan penguatan (reinforcement) dalam rangka pengembangan nilai/karakter.

5. Di lingkungan keluarga dan masyarakat diupayakan agar terjadi proses penguatan dari orang tua/wali serta tokohtokoh masyarakat terhadap perilaku berkarakter mulai yang dikembangkan di satuan pendidikan menjadi kegiatan keseharian di rumah dan di lingkungan masyarakat masing-masing.

Pendidikan karakter harus yang dilakukan secara holistik. Pendidikan 
holistik membentuk manusia secara utuh (holistik) yang berkarakter, yaitu mengembangkan aspek/potensi spiritual, potensi emosional, potensi intelektual (intelegensi \& kreativitas), potensi sosial, dan potensi jasmani siswa secara optimal. Membangun karakter itu harus dimulai sedini mungkin, atau bahkan sejak dilahirkan, dan harus dilakukan secara terus menerus dan terfokus. Pendidikan holistik juga untuk membentuk manusia pembelajar sepanjang hayat yang sejati (lifelong learners). Di samping itu, pendidikan karakter juga mengembangkan semua potensi anak sehingga menjadi manusia seutuhnya. Dalam hal ini, perkembangan anak harus seimbang, baik dari segi akademiknya maupun segi sosial dan emosinya. Pendidikan selama ini hanya memberi penekanan pada aspek akademik saja dan tidak mengembangkan aspek social, emosi, kreatifitas, dan bahkan motorik. "Anak hanya dipersiapkan untuk dapat nilai bagus, namun mereka tidak dilatih untuk bisa hidup”.

Lickona (1991) mengacu pada pemikiran filosof Michael Novak yang berpendapat bahwa watak atau karakter seseorang dibentuk melalui tiga aspek, yaitu: Konsep moral (moral Knowing), sikap moral (moral feeling), perilaku moral (moral behavior). Bagan keterkaitan ketiga konsep tersebut dapat digambarkan sebagai berikut:

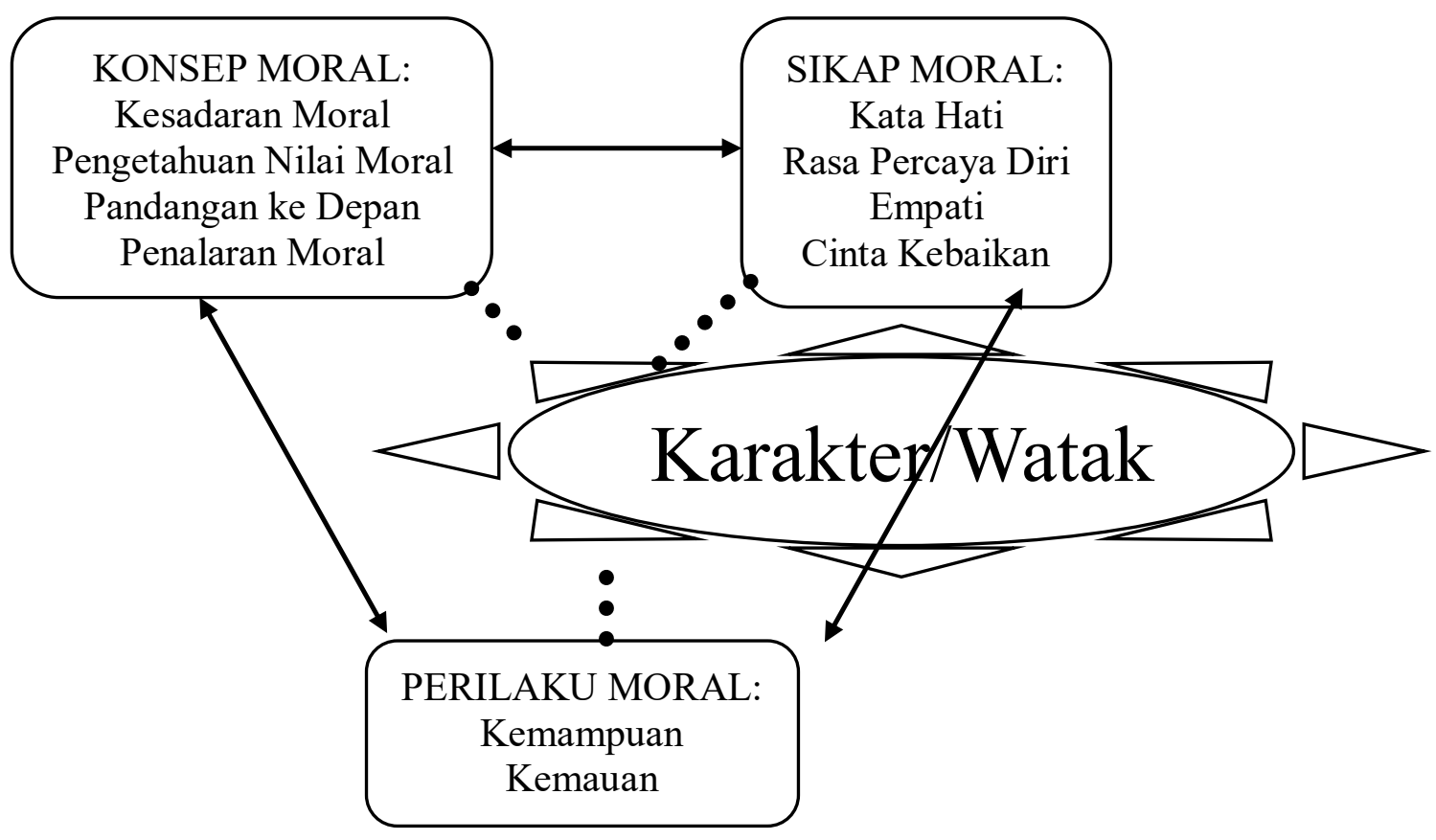


Penelitian ini termasuk kategori penelitian kualitatif dan studi literatur. Dalam penelitian dilakukan penjaringan data tentang pembentukan karakter yang dilaksanakan di pesantren sedangkan penelitian studi literatur yaitu mendata buku-buku teks (kitab kuning) yang digunakan oleh pesantren dalam membentuk karakter bangsa. Metode penelitian yang digunakan untuk studi literatur (penelitian teks), yaitu bertumpu pada analisis konten (teks) dengan mengidentifikasi kitabkitab yang diajarkan di pesantren dan menganalisis muatannya. Dengan menggunakan pendekatan analisis harafiah dan makna, nilai-nilai tertentu terkait dengan nilai-nilai yang mengandung pembentukan karakter akan dikumpulkan dan dianalisis berdasarkan arti harfiah, makna yang tersurat dan tersirat, dan bagaimana cara pengajarannya.

Penelitian dilakukan di beberapa pesantren yang berada di propinsi Sumatera Utara, propinsi Nangroe Aceh Darussalam, propinsi Sumatera Barat, propinsi Riau, propinsi Jambi, dan propinsi Sumatera Selatan. Pengumpulan data dalam penelitian ini dilakukan dengan 2 (dua) tehnik yang lazim digunakan dalam penelitian dalam penelitian kualitatif, yaitu; observasi dan wawancara mendalam. Observasi dilakukan secara nonpartisan, dimana peneliti berperan hanya sebagai pengamat fenomena yang sedang diteliti. Selama penelitian berlangsung, mengamati kegiatankegiatan para pengurus, guru (ustadz) dan santri Pondok Pesantren, melihat bagaimana proses belajar mengajar, khususnya berkaitan dengan pendidikan karakter bangsa berbasis pesantran dan kitab kuning berlangsung.

Wawancara yang digunakan dalam penelitian ini adalah indepth interview dengan pola semi structured interview. Wawancara dilaksanakan terhadap pimpinan pesantren dan pengurus yayasan sekaligus pemrakarsa pendirian Pondok Pesantren untuk mengetahui latar belakang pendirian Pesantren serta hambatan yang dihadapi mulai dari pendirian sampai saat ini. Wawancara juga dilakukan kepada pengelola (kepala sekolah) dan guru (ustadz) yang berperan dan bertanggung jawab terhadap proses pembelajaran di Pondok Pesantren. Wawancara yang dilakukan terhadap pengurus yayasan (kiyai) dan guru (ustadz), peneliti memperoleh informasi tentang perkembangan pesantren dan 
bagaimana proses pembelajarannya dan interview. Kedua, melaksanakan berlangsung. Peneliti juga diminta seleksi atau validasi informasi dengan untuk mendapatkan informasi tentang menggunakan teknik trianggulasi pandangan beberapa tokoh pesantren sehingga diperoleh data yang akurat dan (Kiyai maupun ustadz) mengenai obyektif, dan dalam waktu bersamaan beberapa tema-tema karakter dilakukan coding data. Ketiga, kebangsaan melalui kasus-kasus yang klasifikasi data ke dalam beberapa diangkat.

Untuk studi penelitian kualitatif ini sangat ditekankan pada wawancara tentang nilai-nilai pembentukan karakter di pesantren. Wawancara dilakukan pada pimpinan pondok pesantren, pada ustad dan santrinya. Lebih lanjut dilakukan juga observasi (pengamatan) tentang aplikasi yang dilakukan oleh para santri dalam membentuk nilai-nilai kepribadian yang berhubungan dengan pembentukan karakter bangsa. Kemudian juga dilakukan studi tokoh, yaitu dengan metode indepth interview dengan para tokoh (ustad), santri, pengasuh, dan orang-orang di sekitar lingkungan pesantren.

Dalam kegiatan pengolahan informasi ditempuh beberapa langkah. Pertama, membuat proceeding lengkap secara tertulis dan catatan pinggir (berupa resume) dari semua informasi yang diperoleh dari kegiatan observasi kategori data sesuai topik bahasan penelitian. Selanjutnya, dalam proses analisis data digunakan pendekatan analisis kualitatif. Data yang diperoleh melalui instrumen pengumpulan data disusun secara teratur dan sistematis serta selanjutnya dianalisis secara kualitatif, karena kajian ini dapat juga dikategorikan dan disebut sebagai penelitian kualitatif. Penarikan kesimpulan didasarkan pada pemikiran logis dari data yang diperoleh setelah diberi penjelasan dalam bentuk uraian. Data disajikan sekaligus menganalisisnya (deskriptif analisis), dengan kata lain, agar tidak kehilangan relevansinya, penyajian data tidak dipisahkan dari analisisnya, tetapi dilakukan secara bersamaan. Kompilasi dan pengolahan data penelitian dari semua pesantren dilakukan oleh ketua peneliti bersama tim khusus pengolah data yang sekaligus mengembangkan model pendidikan dan manual prosedur berdasarkan best practices yang 
ditemukan serta mengkaji teori yang relevan. Focus Group Discussion (FGD) dilakukan untuk mengembangkan metode pembelajaran yang dapat digunakan untuk membentuk karakter mulia siswa.

\section{B. HASIL DAN PEMBAHASAN}

Pondok Pesantren sebagai salah satu sub sistem Pendidikan Nasional yang indigenous Indonesia, mempunyai keunggulan dan karakteristik khusus dalam mengaplikasikan pendidikan karakter bagi anak didiknya (santri). Hal itu karena disebabkan karena adanya jiwa dan falsafah serta adanya panca jiwa. Pesantren mempunyai jiwa dan falsafah yang ditanamkan kepada anak didiknya. Jiwa dan falsafah inilah yang akan menjamin kelangsungan sebuah lembaga pendidikan bahkan menjadi motor penggeraknya menuju kemajuan di masa depan. Panca Jiwa yang terdiri dari : a) keikhlasan, b) kesederhanaan, c) kemandirian, d) ukhuwah Islamiyah, dan e) kebebasan dalam menentukan lapangan perjuangan dan kehidupan. Panca jiwa ini menjadi landasan ideal bagi semua gerak langkah pondok pesantren. Implementasi panca jiwa dalam pendidikan sangat diperhatikan di pesantren modern Babussalam Langkat, Sumatera Utara.
Pendidikan dilakukan di pondok pesantren (ponpes) berada dalam situasi yang terkontrol karena pengaruh lingkungan bisa diminimalkan Siswa/santri distrelisasi dari lingkungan yang dapat mempengaruhi moral dan kepribadiannya, bahkan pada ponpes tertentu santri tidak boleh membawa alat komunikasi (HP) seperti di ponpes Syekh Burhanuddin di Riau. Hal tersebut dilakukan untuk meminimalkan faktor utama yang mempengaruhi kepribadian santri yakni media elektronik dan media cetak yang terkait dengan perilaku artis dan pejabat serta tayangan yang tidak mendidik lainnya. Faktor lain yang juga dibatasi adalah pergaulan dengan teman sejawat pada pergaulan yang tidak baik. Dalam kehidupan di ponpes, santri hanya bergaul dengan ustadz/guru dan teman sejawat sesama santri. Pergaulan dengan masyarakat sekitar terbatas pada upaya membangun keperdulian dan semangat gotong-royong. Tentu saja hal tersebut sangat dibutuhkan dalam pembentukan karakter karena "karakter bangsa" yang sudah mulai pudar adalah gotong royong serta menghargai perbedaan dan pendapat orang lain yang seharusnya diwujudkan dalam tepa selira. 
Metode pengajaran di pesantren Salafiyah, misalnya pesantren Syekh Burhanuddin diberikan dalam bentuk, sorogan, bandong, halaqah dan hafalan. Sorogan artinya: belajar secara individual dimana seorang santri berhadapan dengan seorang guru, terjadi interaksi saling mengenal antara keduanya. Bandongan artinya belajar secara kelompok yang diikuti seluruh santri, dan biasanya Kiyai mengunakan bahasa daerah setempat dan langsung menterjemahkan kalimat demi kalimat dari kitab yang dipelajarinya, halaqah artinya diskusi untuk memahami isi kitab, bukan untuk mempertanyakan kemungkinan benar salahnya apa yang diajarkan oleh kitab, tetapi untuk memahami apa maksud yang diajarkan kitab. Santri yakin bahwa Kiyai tidak akan mengajarkan hal-hal yang salah dan juga mereka yakin bahwa isi kitab yang dipelajari adalah benar. Masih dalam kegiatan proses belajar mengajar santrinya biasanya seminggu sekali pada saat shalat isya dan subuh, mengadakan belajar pidato atau belajar memberikan ceramah keagamaan, ceramah keagamaan terserah pada santri/santriwati, tetapi kebanyakan berkisar pada sejarah Nabi Muhammad Saw, kepahlawan, kejujuran para sahabat dan tema-tema aktual sifatnya, dan juga belajar memberikan kata sambutan dalam berbagai hal, misalnya kemalangan dan kata sambutan lainnya yang dianggap perlu untuk di sampaikan, dan semua santri yang dalam satu kelompok yang disebut dengan khalifah, dan diketuai oleh seseorang dan jumlah santrinya berkisar lebih kurang 30 orang, dan semua santri wajib berpidato atau memberikan kata sambutan dalam berbagai hal, yang sangat unik dilihat dalam satu kelompok khalifah ini dipilih secara demokratis dari santri yang hadir, dan tidak ada yang keberatan jika pilihannya kalah. Satu kelompok khalaqah tersebut terdiri dari berbagai kelas, dari kelas I s/d kelas VII, jika mereka tidak bisa memberikan pidato dan ceramah keagamaan yang berdurasi lebih kurang 10 menit dan selesai sampai jam 10 malam dan presentasinya sudah dijawalkan dan lebih kurang berjumlah 7 orang atau 10 orang santri, maka mereka dihukum, sampai kegiatan tersebut selesai dilakukan, yang sangat unik disini tidak ada ustad dan ustazah yang mengawasinya, inilah sebenarnya menanamkan kejujuran sejak usia dini dilakukan, tujuannnya supaya santri mandiri dan berusaha dengan 
sekuat tenaga untuk menyiapkan materi yang akan disampaikan. Metode pembelajaran dengan menceritakan keteladanan rasul dan menanamkan kejujuran sudah mulai hilang di sekolah dan masyarakat, padahal metode tersebut cukup efektif untuk anak usia dini.

Namun untuk menumbuhkan kemampuan berpikir rasional sejak permulaaan berdiri sampai sekarang pesantren Syekh Burhanudin menyadari perlunya pelajaran umum diberikan di pesantren, dan juga diperkenalkan keterampilan khusus di pesantren, seperti bertani, berternak, bertukang dan pekerjaan lainnya telah akrab dengan kehidupan sehari-hari, dan biasanya kegiatan ini mereka lakukan jika hari libur, tujuannya adalah untuk mengembangkan wawasan dan orientasi santri dari pandangan hiduap yang terlalu berat pada ukhrawi, agar menjadi seimbang dengan orientasi kehidupan duniawi. Adapun prinsif sistem pendidikan pesantren dari pengamatan di lapangan maka dapat dirumuskan sebagai berikut:

\section{Theocentric}

Sistem pendidikan pesantren mendasarkan filsafat pendidikannya pada filsafat theocentric, yaitu pandangan yang menyatakan bahwa sesuatu kejadian berasal, berproses, dan kembali kepada kebenaran Allah Swt. Semua aktivitas pendidikan dipandang sebagai ibadah kepada Allah Swt. Semua aktivitas pendidikan merupakan bagian integral dari totalias kehidupan keagamaan, sehingga kegaitan belajar mengajar tidak memperhitungkan waktu. Dalam praktiknya cenderung mengutamakan sikap dan prilaku yang sangat kuat beroreintasi kepada kehidupan ukhrawi dan berprilaku sakral dalam kehidupan sehari-hari. Semua perbuatan dilaksanakan dalam struktur relevansinya dengan hukum agama demi kepentingan hidup ukhrawi.

\section{Sukarela dalam mengabdi}

Para pengasuh pondok pesantren memandang semua kegiatan pendidikan adalah ibadah kepada Allah Swt. Sehubungan dengan itu penyelenggaraan pesantren dilaksanakan secara sukarela dan mengabdi kepada sesama dalam rangka mengabdi kepada Allah Swt. Mengingat biaya masuk ke pesantren Syekh Burhanuddin sama sekali tidak memungut biaya, maka honor 
dan gaji para Kiyai, ustad dan guru tidak tahu dari mana bila menurut anak pendiri pesantren tersebut, tapi ada saja, dan satu yang ditanamkan ayahnya kalau mencari makan jangan dipesantren tapi silakan kerja atau ngajar ketempat lain untuk memenuhi kebuthan hidup untuk istri dan anaknya. Santri merasa wajib menghormati Kiyai dan ustadnya serta saling menghargai sesamanya, sebagai bagian perintah dari agama. Santri yakin bahwa dirinya tidak akan menjadi orang berilmu tanpa guru dan bantuan sesamanya.

\section{Kearifan}

Pesantren Syekh Burhanuddin menekankan pentingnya kearifan dalam menyelenggarakan pendidikan pesantren dan dalam tingkah laku sehari-hari. Kearifan yang dimaksud disini adalah bersikap berlaku sabar, rendah hati, patuh pada ketentuan hukum agama, mampu mencapai tujuan tanpa merugikan orang lain, dan mendatangkan manfaat bagi kepentingan bersama, jika dilihat dari pesantren Syekh Burhanuddin maka memberikan kebebasan pada santri untuk membentuk jati dirinya sebagai santri yang tunduk dan taat pada aturan pesantren.

4. Kesederhanaan

Pesantren Syekh Burhanuddin menekankan pentingnya penampilan sederhana sebagai salah satu nilai luhur pesantren dan menjadi pedoman prilaku sehari-hari bagi seluruh santri/santriwati. Kesederhanaan yang dimaksudkan disini adalah, tidak tinggi hati dan sombong pada santri lain walaupunn dia dari golongan orang kaya, ada satu hal yang unik dari pengasuh pondok pesantren jika mereka mau membeli mobil atau keperluan prabot rumah tangga, maka para pengasuh pondok pesantren berdiskusi dengan santri/santriwati dan memberikan penerangan bahwa apa yang mereka beli memang adalah kebutuhan yang sangat mendesak sekali, misalnya mobil, dan akhirnya para santri menerimanya, atau kalau seandainya mau menjual dan menganti mobil lain maka disini terjadi diskusi, supaya jangan ada salah paham dengan santri lain, hal ini sebenarnya wajar, mengingat tidak ada sama sekali biaya yang dikutip dari santri, dari uang masuk, makan, 
penginapan, uang bulanan dan lainlain.

\section{Kolektivitas}

Pesantren Syekh Burhanuddin menekankan kebersamaan lebih tingi dari pada kepentingan pribadi. Dalam dunia pesantren berlaku pendapat bahwa "mengutamakan kepentingan orang banyak dari pada kepentingan pribadi, tetapi dalam hal kewajiban orang harus mendahulukan kewajiban diri sendiri sebelum orang lain, sedang dalam hal memilih atau memutuskan sesuatu "santri harus memelihara hal-hal baik yang telah ada, dan mengembangkan hal-hal yang baru yang baik. Kedua nilai tetap berlaku, dan kamar tidur yang berukuran $2 \mathrm{x}$ $3 \mathrm{~m}$ ditempati dua atau tiga santri, dan kamar tersebut adalah berdinding papan dan beralaskan papan, dan yang lebih uniknya bangunan kamar itu adalah dibangun oleh santri tersebut dengan cara saling membantu, dan bangunan tersebut jika santri sudah selesai maka dengan ikhlas diberikan kepada generasi berikutnya, sedangkan santriwati ada bangunan khusus yang permanen yang telah disiapkan pondok pesantern, dan mereka juga saling menolong satu sama lain, jika terlambat uang kiriman dari uang tuanya, maka mereka berusaha bersama untuk membantu meringankan rekannya tersebut., Mengatur Kegiatan Bersama

Kegiatan bersama yang dilakukan oleh para santri bisanya bersifat relatif dan mengikat, dilakukan oleh santri dengan bimbingan ustad dan kiayai. Para santri mengatur hampir semua kegiatan proses belajar mengajar terutama berkenaan dengan kegiatan kokurikurer, dari pembentukan, penyusunan sampai pelaksanaan dan pengembangannya, dan juga mengatur kegiataan, peribadatan, olah raga kursus-kursus keterampilan dan sebagainya. Selama kegiatan dan apa yang direncanakan oleh santri tidak menyimpang dari Islam dan ketentuan pesantren.

6. Ukhuwah Diniyah

Kehidupan diliputi dengan suasana persaudaraan yang akrab, persatuan dan gotong royong, sehingga segala kesenangan di rasakan bersama dan kesulitan dapat diatasi bersama. Hal ini dapat 
terwujud karena keyakinan dan pandangan hidup mereka sama, bahwa manusia di ciptakan dan berada di bumi ini tidak lain hanyalah untuk mengabdi kepada sang kholik, yaitu Allah SWT. Sebagai hamba yang beriman (mukmin) mereka akan merasa bersaudara dengan sesama dan berbuat baik terhadap mereka.

\section{Kebebasan}

Kebebasan yang dimaksud adalah kebebasan dari segi kurikulum dan bebas secara politis. Kebebasan dari sisi kurikulum berarti bahwa pondok Pesantren Syekh Burhanuddin tidak terikat oleh kurikulum Departemen Agama maupun Departemen Pendidikan Nasional. Sedangkan kebebasan secara politis Pesantren Syekh Burhanuddin merupakan lembaga independen, tidak berafiliasi bahkan terlibat pada salah satu pada partai politik maupun ormas tertentu. Dalam konteks santri, kebebasan di sini berarti penanaman sikap demokratis. Mereka bebas berpikir, bebas dalam menentukan jalan hidupnya kelak di masyarakat, optimis dalam menghadapi hidup ini.
Namun semua itu dilakukan dalam batas-batas syari'at Islam.

Situasi pembelajaran dengan kondisi terkontrol tersebut dapat diterapkan pada sekolah penuh hari (full-day school). Namun tidak semua faktor lingkungan dapat dikontrol sehingga beberapa penyesuaian harus dilakukan. Kondisi lain yang sangat berbeda dengan karakteristik ponpes adalah keteladanan yang ditunjukkan oleh kiyai/ustadz. Aspek afektif sangat besar porsinya pada pendidikan di ponpes, sedangkan aspek kognitif lebih dominan pada pendidikan umum (nonpesantren). Besarnya aspek afektif dapat dilihat dari keikhlasan ustadz mengajar dengan bayaran yang minim bahkan ada yang mengajar secara sukarela (tidak dibayar). Membentuk siswa yang memiliki jiwa yang ikhlas merupakan suatu permasalahan tersendiri di sekolah formal yang tidak memiliki guru yang perhatian kepada siswa. Jadi untuk dapat menerapkan pendidikan karakter, pengelola sekolah ataupun pemerintah harus menetapkan standar khusus dan perekrutan untuk mendapatkan guru yang memenuhi syarat.

Ponpes salafiyah tidak memiliki kurikulum yang jelas, sedangkan 
ponpes modern memiliki kurikulum dan standar pembelajaran yang jelas. Pembentukan karakter tidak dititipkan dalam tiap pelajaran yang diberikan tapi dilakukan secara holistic dengan menerapkan aturan, keteladanan, dan hal-hal lain yang dapat dijadikan model bagi pendidikan di sekolah umum. Pendidikan holistik membentuk manusia secara utuh (holistik) yang berkarakter, yaitu mengembangkan aspek/potensi spiritual, potensi emosional, potensi intelektual (intelegensi \& kreativitas), potensi sosial, dan potensi jasmani siswa secara optimal. Kondisi ini berbeda dengan grand design pendidikan karakter yang dicanangkan oleh Kemendiknas, dimana pendidikan karakter dititipkan pada masing-masing mata pelajaran.

Pesantren menanamkan beberapa atribut karakter, diantaranya: 1) cinta terhadap Allah SWT, RasulNya dan segenap ciptaanNya: Hal inilah yang menjadi perbedaan antara sekolah umum dengan pesantren. Pesantren lebih menonjolkan agar para santrinya agar tidak melupakan siapa yang menciptakannya yakni Allah SWT dengan mewajibkan baik ibadah wajib ataupun sunnah yang mereka selalu melakukan hal ini secara berjama'ah seperti sholat dhuha dan sholat tahajud serta puasa sunnah. 2) Jujur: kantin dan koperasi biasanya dikelola oleh santri dengan bimbingan dari ustadz/ustadzah yang bersangkutan. Transaksi di kantin tersebut biasanya dilakukan sendiri yakni tanpa penjaga. Hal inilah yang melatih kejujuran dengan takut kepada Allah atas dosa yang akan mereka dapat jika tidak membayar secara jujur. Di pesantren juga terdapat buku laporan tentang sholat berjamaah dan ibadah sunnah lainnya. Hal ini akan mendidik kejujuran santri dalam melakukan ibadah karena takut pada Allah bukan takut pada aturan pesantren. 3) Kemandirian: di pesantren selalu diajarkan kemandirian dari para santrinya, yakni segala sesuatu menyangkut keperluan dirinya baik dari makan dan pakaian akan diurus sendiri. 4) Kesederhanaan: di Pesantren hidup sederhana sangat diajarkan karena Allah sangat membenci hal berlebihan. Di pesantren mulai dari berpakaian, makan dan minum dituntut untuk keserhanaan, tidak pandang bulu santri berasal dari kalangan ekonomi tinggi atau rendah di pesantren semua disetarakan dan tidak ada perbedaan pelayanan dan aturan. 5) Disiplin: pesantren memiliki aturan yang lebih ketat dari pada sekolah 
umum. Aturan ini berlaku 24 jam. Mulai dari santri terbangun hingga tertidur kembali ada aturannya. Hal ini mendidik kedisiplinan tinggi dan belajar menghargai waktu karena pesantren sadar Allah pernah bersabda "demi masa sesungguhnya manusia kerugian". Jadi alangkah lebih baiknya jika waktu kita manfaatkan sedemikian rupa dalam hal kebaikan. Best practices lain yang diamati di beberapa ponpes adalah kegiatan kebersamaan melalui gotong royong. Pada umumnya kegiatan di ponpes dilakukan berdasarkan pada panca jiwa (keikhlasan, kesederhanaan, kebersamaan, ukhuwah islamiyah). Disiplin jugaditerapkan pada pendidikan di pesantren dengan menetapkan jadwal kegiatan, aturan, dan sanksi yang ketat. Disiplin sangat dibutuhkan untuk membentuk santri/siswa yang mampu bekerja keras (dengan gigih dan bersemangat), tentu saja juga harus dilakukan secara cerdas (kognitif). Aspek disiplin juga akan membentuk karakter siswa yang bertanggung jawab dalam melakukan aktivitas dan gigih dalam berupaya mencapai sesuatu yang diinginkan. Tentu saja, aspek disiplin ini perlu dilatih dengan membuat peraturan yang harus dipatuhi, sesuai pernyataan Stein
(2000), "We can use the guiding principles of character and conduct to make our school communities safer, better disciplined, and more welcoming places to learn and work".

Berdasarkan best practices di beberapa ponpes yang diteliti, dapat dikembangkan desain pembelajaran yang dapat diterapkan oleh lembaga pendidikan. Namun perlu dilakukan beberapa penyesuaian, mengingat perbedaaan karakeristik pendidikan di sekolah umum dengan siswa yang lebih rasional dengan pendidikan di pesantren yang memiliki iklim keteladanan dan kepercayaan penuh kepada ustadz. Beberapa hal yang perlu diperhatikan dalam pembentukan karakter pada sekolah umum adalah knowing the good. Untuk membentuk karakter, anak tidak hanya sekedar tahu mengenai halhal yang baik, namun mereka harus dapat memahami kenapa perlu melakukan hal tersebut. Selama ini banyak orang yang tahu bahwa ini baik dan itu buruk, namun mereka tidak tahu apa alasannya melakukan hal yang baik dan meninggalkan hal-hal yang tidak baik. Jadi masih ada gap antara knowing dan acting. Pada pendidikan di sekolah umum, siswa sebaiknya memahami pentingnya memiliki atribut karakter 
dan menyadari manfaatnya bagi maka sifat empati, toleransi, peduli, dan kehidupan di masyarakat.Tahapan yang gotong royong akan terbentuk pada diajukan dalam teori adalah sebagai kepribadian siswa. Peningkatan berikut: Curiousity (timbulkan rasa emotional quotient (EQ) yang dilandasi ingin tahu anak), Share (ajak oleh kasih sayang kepada sesama berdiskusi), Planning (apa yang akan manusia sangat perlu dilakukan sejak dilakukan), Action (anak melakukan dini untuk mengantisipasi maraknya rencana yang disusun), dan Reflection perpecahan dan konflik di kalangan (anak mengevaluasi apa yang telah ia masyarakat. Stevenson (2006) lakukan). Untuk membentuk disiplin mengatakan, "Without a sense of caring perlu dibuat beberapa aturan dan jadwal there can be no sense of community". kegiatan yang harus dipatuhi oleh siswa, Untuk membentuk masysrakat madani, kemudian siswa diajak berdiskusi perlu dilakukan pendidikan yang tentang aturan/tata tertib beserta membangun individu yang senantiasa sanksinya, siswa juga perlu diajak ikhlas membantu orang lain dan tepa bertukar pikiran tentang tujuan dan selira. Pembentukan karakter ikhlas manfaat pelaksanaan kegiatan. Integrasi pembentukan disiplin dalam mata pelajaran adalah penuntasan tugas yang diberikan secara bertanggung jawab dengan rencana kerja yang jelas. Dalam kasus ini siswa diminta membuat refleksi tentang apa yang mereka lakukan dan kendala yang ditemui dalam menyelesaikan tugas atau kegiatan yang diberikan oleh guru.

Atribut karakter lain yang perlu dikembangkan dan sangat terkait dengan karakter kebangsaan adalah kemauan dan kemampuan membantu orang lain. Dengan membiasakan siswa membantu orang lain secara ikhlas, result, one hopes, will be middle 
schools, high schools, and penelitian ini, atribut karakter yang neighborhoods in which young people paling penting untuk dibentuk adalah care about one another and work with kejujuran, disiplin, dan saling tolong their classmates and neighbors to menolong.

develop team spirit”. Karakter tolong menolong yang berakar dari kepedulian terhadap orang lain merupakan karakter yang dibutuhkan dalam membentuk seorang siswa menjadi pemimpin, seperti dideskripsikan oleh Klaan (2007) tentang pemimpin yang baik: “.... good leader you have known and mentally assigned words and concepts like competent, trustworthy, positive, dependable, cared about people, or kept us informed". Untuk dapat membentuk karakter kepemimpinan yang peduli, maka perlu dilatihkan kebiasaan dan kemampuan memecahkan permasalahan masyarakat sekitar, sesuai dengan saran Baptiste (2009), "Being a leader means first identifying a problem and then finding ways to solve that problem".

\section{SIMPULAN}

Pembentukan karakter harus dilakukan di sekolah dengan mempertimbangkan interaksi siswa terhadap lingkungan (keluarga dan masyarakat). Oleh sebab itu pendidikan karakter harus dilakukan secara holistik secara terprogram. Berdasarkan
Untuk merealisasikan dan mengembangkan pendidikan karakter nasional bangsa ada beberapa hal yang memerlukan perhatian pemerintah dan masyarakat: yang pertama adalah penyiapan lembaga pendidikan yang berkualitas, kedua adalah penyiapan tenaga pendidik terutama para kepala sekolah yang mempunyai kapabilitas serta integritas kepribadian tinggi dan yang ketiga adalah penciptaan lingkungan yang kondusif bagi pendidikan karakter anak bangsa. Pertama penyiapan lembaga pendidikan yang berkualitas. Lembaga pendidikan yang mempunyai orientasi character building, mementingkan pendidikan yang integral, mengembangkan dan meningkatkan potensi anak didik dalam segala aspek kemanusiannya. Pendidikan yang berbasis nilai, melakukan transformasi kepribadian, akhlak, tingkah laku, pola fikir dan sikap. Bukan hanya mentransfer informasi dan pengetahuan semata (aspek kognitif) dengan melalaikan aspek afektif dan spikomotorik. Kedua menyiapkan 
tenaga pendidik terutama kepala-kepala sekolah yang handal untuk merealisasikan tujuan yang ditargetkan. Tenaga pendidik merupakan ujung tombak bagi keberhasilan tujuan pendidikan. Tenaga pendidik dan kepala sekolah yang mencintai tugasnya, mempunyai ruh dan semangat idealisme tinggi, berdedikasi dan mempunyai integritas moral tangguh, mempunyai kecakapan menejerial dan mampu menjadi teladan dalam segala hal bagi anak didiknya. Mereka harus dipersiapkan sedemikian rupa agar mampu menyesuaikan diri dengan perubahan-perubahan yang terjadi dengan senantiasa meningkatkan diri dan memperbaharui pengetahuan (refresh/up-date), bersikap terbuka terhadap hal-hal baru (open mind) dan bersikap bersedia membantu (helpful).

Diperlukan stabilitas nasional, dukungan keluarga, masyarakat, LSM maupun lembaga lain merupakan pilarpilar pendukung bagi keberlangsungan iklim pendidikan yang produktif dan berdampak positif bagi terciptanya karakter bangsa peserta didik. Pusat penelitian kebijakan seharusnya membuat usulan pengembangan kebijakan kepada pemerintah berupa: a) penetapan keharusan pencanangan misi sekolah mencakup misi pengembangan karakter siswa, b) penetapan keharusan bagi sekolah untuk membuat dan melaksanakan program pengembangan karakter (terutama: jujur, tolong menolong, dan bertanggungjawab) secara holistik dengan melibatkan orang tua dan masyarakat dengan pengontrolan oleh semua guru, c) penetapan keharusan menegakkan disiplin dan keteladanan di lingkungan sekolah.

\section{DAFTAR PUSTAKA}

Arthur, James. (2003). Education with Character, New York: Routledge-Falmer.

Baptiste, Tracey. (2009). Being a leader and making decisions, New York: Infobase Publishing

Kessler, Rachael. (2000). The Soul of Education: Helping Student to Find Connection, Compassion, and Character at School, Alexandria: ASCD.

Klann, Gene. (2007). Building character: strengthening the heart of good leadership, San Fransisco: John Wiley and Sons

Lickona, T. (1991). Educating for Character: How Our Schools Can 
Teach Respect and Responsibility, Stein, Rita Prager. (2000). Connecting

New York: Bantam

Miller, Marie-Therese. (2009). Managing Responsibilities, New York: Infobase Publishing

Rich, Dorothy. (2008). Megaskills: Building your child's happiness and success in school and life, Illinois: Sourcebooks, Inc. character to conduct : helping students do the right things, Alexandria: ASCD.

Stevenson, Nancy. (2006). Young Person's Character Education Handbook, Indianapolis: JIST Publishing, Inc. 